\title{
Neutral Endopeptidase-like Enzyme Controls the Contractile Activity of Substance P in Guinea Pig Lung
}

\author{
Norma P. Stimler-Gerard \\ Pulmonary Unit, Department of Medicine, Beth Israel Hospital, and the Thorndike Laboratory \\ of Harvard Medical School, Boston, Massachusetts 02215
}

\begin{abstract}
The responsiveness of isolated guinea pig lung parenchymal strips to substance $P$ was enhanced by at least 100 -fold in the presence of the endopeptidase inhibitors phosphoramidon $(1 \mu \mathrm{M})$ or thiorphan (1 $\mu \mathrm{M})$, but not with the converting enzyme inhibitor, captopril, or an inhibitor of serum carboxypeptidase $\mathbf{N}$ (both 1 $\mu M)$. Responses of guinea pig tracheal rings to substance $P$ were also markedly potentiated by phosphoramidon. The increase in tissue responsiveness by these inhibitors was relatively specific for substance $P$ among several other spasmogenic peptides, including formyl-methionyl-leucyl-phenylalanine and the complement peptides $\mathrm{C} 3 \mathrm{a}$ and $\mathrm{C5a}$. The enhanced responses appear to result from a decrease in the rate of substance $P$ degradation in the presence of neutral endopeptidase inhibitors. Specific binding of substance $P$ to its receptor on bronchial membranes was increased by three- to fourfold in the presence of phosphoramidon. These data demonstrate an enhanced potential for substance $P$ to contract lung tissues when degradation by a neutral endopeptidase-like enzyme is blocked.
\end{abstract}

\section{Introduction}

Substance $P$ is a naturally occurring 11-residue peptide which has been shown to participate in neurogenic bronchoconstriction (1-5). The peptide has been identified by immunohistochemical techniques in neural fibers of guinea pig trachea and bronchus, and is depleted upon vagal stimulation or prolonged treatment with capsaicin (5), the pungent agent of hot peppers. Intravenous administration of substance $P$ in guinea pigs causes acute bronchospasm, hypotension, and increases in vascular permeability (4). In vitro, substance $P$ has also been shown to contract isolated guinea pig tracheal and lung parenchymal tissues in a muscle bath apparatus (6-8). Pharmacologic studies have shown that the contractile effects of the peptide are independent of histamine, catecholamines, and serotonin $(5,6,8)$. Variable results have been reported with cyclooxygenase inhibitors, one group observing enhanced responses in the presence of indomethacin (8), and another group finding no change with meclofenamate (6). Similarly, atropine was found either to have no effect on (5), or to cause potentiation of substance $P$ responses (6). Since no inhibitors of secondary mediators have yet been shown to block

Address correspondence and reprint requests to Dr. Stimler-Gerard, Pulmonary Unit, Dept. of Medicine, Beth Israel Hospital, 330 Brookline Ave., Boston, MA 02215.

Received for publication 27 October 1986 and in revised form 15 December 1986.

J. Clin. Invest.

(c) The American Society for Clinical Investigation, Inc. 0021-9738/87/06/1819/07 $\$ 1.00$

Volume 79, June 1987, 1819-1825 substance $\mathrm{P}$-induced spasmogenic activity in vitro, it is thought that the peptide may act directly on smooth muscle $(5,9)$.

A recent report demonstrated that substance $P$ is a substrate for human kidney neutral endopeptidase (EC 3.4.24.11) (10), an enzyme originally characterized for its ability to degrade enkephalins (11). This enzyme has substrate specificity similar to that of thermolysin $(12,13)$. It is thought to be an integral membrane protein and has been localized immunohistochemically to lung and kidney epithelium, neutrophil membranes, and brain (14-16). Like thermolysin, it is inhibited by the substrate analogues, phosphoramidon and thiorphan (17-20). Its presence in brain and ability to degrade enkephalins and substance $P$ have been interpreted as indicating a primary function of the enzyme in catabolizing these neuropeptides $(16,21,22)$.

In the case of other spasmogenically active peptides, bradykinin and the complement anaphylatoxins, C3a, C4a, and $\mathrm{C} 5 \mathrm{a}$, protease or exopeptidase activity has been demonstrated to provide an effective control mechanism $(23,24)$. We reasoned that the relatively weak spasmogenic activity of substance $P$ on guinea pig lung parenchymal strips could be due to its rapid degradation. To test this hypothesis, we examined the effect of inhibiting proteolytic activity on substance $P$ responses in this tissue. Our findings demonstrate marked potentiation of contractile activity in the presence of neutral endopeptidase inhibitors.

\section{Methods}

Reagents and buffers. Substance P, D-Pro ${ }^{2}$, D-Trp ${ }^{7}$, D-Phe'-substance $\mathrm{P}$, formyl-methionyl-leucyl-phenylalanine (fMLP), ${ }^{1}$ phosphoramidon, chymostatin, leupeptin, bacitracin, and acetylcholine (ACh) were all obtained from Sigma Chemical Co, St. Louis, MO. ${ }^{125}$ I-Substance P (labeled with Bolton and Hunter reagent) was purchased from Amersham Corp., Arlington Heights, IL. Captopril (SQ 14,225) was a generous gift of The Squibb Institute for Medical Research, Princeton, NJ. DL-2-mercaptomethyl-3-guanidinoethylthiopropanoic acid (MGPA) was purchased from Calbiochem-Behring Corp., San Diego, CA, and thiorphan was purchased from Peninsula Laboratories, Belmont, CA. Human C5a was obtained as a recombinant peptide from Escherichia coli lysates, reconstituted and purified as previously described (25). C3a was purified from complement-activated porcine serum as described (26). The buffer used throughout was a modified Tyrode's solution which contained $137 \mathrm{mM}$ $\mathrm{NaCl}, 2.7 \mathrm{mM} \mathrm{KCl}, 1.8 \mathrm{mM} \mathrm{CaCl}_{2}, 1 \mathrm{mM} \mathrm{MgCl}, 0.36 \mathrm{mM} \mathrm{NaH}_{2} \mathrm{PO}_{4}$, $12 \mathrm{mM} \mathrm{NaHCO}_{3}$, and $5.5 \mathrm{mM}$ dextrose, $\mathrm{pH} 7.4$ (27).

Preparation of lung strips. Male Hartley guinea pigs of $300-500 \mathrm{~g}$ (Charles River Breeding Laboratories) were the source of all tissue preparations. Lung parenchymal strips were prepared from lungs perfused with Tyrode's buffer using a modification of the method previously described (28). 20 parenchymal strips, 1-2 mm thick, were prepared from each animal, cut as cross-sections of individual lobes, and used in two

1. Abbreviations used in this paper: ACh, acetylcholine; fMLP, formylmethionyl-leucyl-phenylalanine; MGPA, DL-2-mercaptomethyl-3guanidinoethylthiopropanioc acid; TFA, trifluoracetic acid. 
groups of ten on a single day. Control studies indicate that these tissues can be stored in Tyrode's buffer at $25^{\circ} \mathrm{C}$ for at least $8 \mathrm{~h}$ with no significant loss in responsiveness. Lung strips were mounted in organ baths filled with Tyrode's buffer at $37^{\circ} \mathrm{C}$, aerated with $95 \% \mathrm{O}_{2}, 5 \% \mathrm{CO}_{2}$, and attached to force-displacement transducers (FT .03C; Grass Instrument Co., Quincy, MA) under a resting force of $300 \mathrm{mg}$. Tissues were equilibrated for 20-60 min at this force, and contractile responses stimulated by addition of agonists to the bathing fluid were recorded at $10 \mathrm{~mm} / \mathrm{min}$ (model 7 polygraph, Grass Instrument $\mathrm{Co}_{\text {;). }}$. For each experiment, all tissues were first challenged with $2 \mu \mathrm{g} / \mathrm{ml} \mathrm{ACh}$ to assess their responsiveness. This concentration induces a maximal or near-maximal tissue response to $\mathrm{ACh}$. Subsequent responses are reported as the increase in force induced by an indicated agonist relative to that caused by $2 \mu \mathrm{g} / \mathrm{ml}$ $\mathrm{ACh}$, and data are expressed as the mean $\pm \mathrm{SE}$ of at least four individual responses. This normalization process is required to eliminate variations in responses due to tissue size and muscle content, and, at least for substance $\mathbf{P}$, additionally eliminates variations among tissues from different animals. Lung strips were then washed and allowed to return to their original resting force before addition of agonist peptide at the desired concentration. Each lung strip received only one dose of an agonist peptide. Substance P, D-Pro ${ }^{2}$, D-Phe ${ }^{7}, \mathrm{D}-\mathrm{Trp}^{9}$-substance P, and the anaphylatoxin peptides, C3a and C5a, were dissolved in aqueous solution; fMLP was dissolved in dimethylsulfoxide (DMSO). For experiments done to test the effects of protease inhibitors, phosphoramidon, thiorphan, captopril, or MGPA were added from concentrated stock solutions in DMSO (for phosphoramidon and thiorphan) or water (for captopril and MGPA) $10 \mathrm{~min}$ before the agonist. DMSO concentrations in the bathing fluid did not exceed $0.1 \%$ and had no effect on the responses observed.

Preparation of guinea pig tracheal rings. Guinea pig tracheal rings were prepared similarly to previously described methods (29). Five to eight rings of 2-3 mm width were cut from each trachea. The cartilage was cut at a point opposite the trachealis muscle and the tissues mounted in organ baths under a resting force of $2 \mathrm{~g}$. Tissues were allowed to equilibrate for $60 \mathrm{~min}$ before challenge with $\mathrm{ACh}$ as described above. Subsequent experiments were carried out in the same manner as for parenchymal strips.

Recovery of substance $P$ from lung strips. Lung parenchymal tissues were prepared as described above for muscle bath experiments and placed in Tyrode's buffer at $160 \mathrm{mg}$ wet weight tissue in $5 \mathrm{ml}$ buffer, at $37^{\circ} \mathrm{C}$ in the presence of $1 \mu \mathrm{M}$ phosphoramidon; $1 \mu \mathrm{M}$ captropril, $1 \mu \mathrm{M}$ MGPA, or vehicle alone. Tissues were preincubated with the inhibitor for $5 \mathrm{~min}$, substance $P$ was added to a final concentration of $1 \mu \mathrm{M}$, and incubation was continued an additional 5 min. Degradation was terminated by transferring each supernatant solution to a second tube containing acetic acid to make $1 \mathrm{M}$ and lyophylized. Samples were redissolved in 0.5 - and $0.1-\mathrm{ml}$ aliquots (equivalent to $1 \mathrm{nmol}$ undigested peptide) injected on an Anspec $\mathrm{C} 18$ reverse-phase high performance liquid chromatography (HPLC) column. Substance $P$ was resolved with a two-step linear gradient from 6 to $18 \%$ acetonitrile in $0.1 \%$ trifluoroacetic acid (TFA) over $5 \mathrm{~min}$, followed by a gradient from 18 to $48 \%$ acetonitrile in $0.1 \%$ TFA over $20 \mathrm{~min}$. The column was eluted at $1 \mathrm{ml} / \mathrm{min}$ and monitored at $220 \mathrm{~nm}$. Under these conditions substance $P$ elutes at $14.5-15 \mathrm{~min}$. The amount of intact peptide remaining was determined from the peak height relative to peak heights established for known standards.

Rate of substance $P$ degradation. Guinea pig lung membranes were prepared essentially according to procedures described previously (30). Lungs from three guinea pigs were perfused with Tyrode's buffer and homogenized by polytron (Brinkmann Instruments Inc., Westbury, NY) in 10 vol of ice-cold $50 \mathrm{mM}$ Tris- $\mathrm{HCl}, \mathrm{pH} 7.0$, for three 10-s periods at setting 6 . The homogenates were centrifuged at $1 ; 000 \mathrm{~g}$ for $10 \mathrm{~min}$. The supernatants were then centrifuged at $40,000 \mathrm{~g}$ for $15 \mathrm{~min}$. Pellets ob-

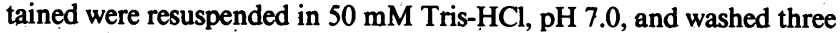
times by centrifuging for $15 \mathrm{~min}$ at $40,000 \mathrm{~g}$. Pelleted material was finally resuspended in the same buffer at $0.5 \mathrm{mg}$ protein $/ \mathrm{ml}$ and incubated with $100 \mu \mathrm{M}$ substance $\mathrm{P}$, and $1 \mu \mathrm{M}$ phosphoramidon, $1 \mu \mathrm{M}$ MGPA, or vehicle alone at $37^{\circ} \mathrm{C}$, removing duplicate $100-\mu \mathrm{l}$ aliquots at various times up to $20 \mathrm{~min}$. Degradation was stopped by heating the mixtures to $110^{\circ} \mathrm{C}$ for $5 \mathrm{~min}$ followed by centrifugation at $7,000 \mathrm{~g}$ for $2 \mathrm{~min}$. The amount of intact substance $P$ remaining was quantitated by reversephase HPLC as described above and the rate of degradation was determined by regression analysis of the substance $P$ remaining as a function of time.

Effect of phosphoramidon on substance $P$ binding to bronchial membranes. Guinea pig lungs $(n=3)$ were mechanically stripped of as much alveolar tissue as possible. The remaining bronchial tissues were ho-

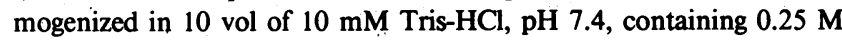
sucrose, $100 \mu \mathrm{g} / \mathrm{ml}$ bacitracin, and $0.1 \mathrm{mM}$ PMSF, for six 10-s periods on ice. The homogenate was centrifuged at $1,000 \mathrm{~g}$ for $10 \mathrm{~min}$. The supernatant was centrifuged at $30,000 \mathrm{~g}$ for $30 \mathrm{~min}$, then pelleted material was resuspended in $50 \mathrm{mM}$ Tris- $\mathrm{HCl}, \mathrm{pH} 7.4$, containing $3 \mathrm{mM} \mathrm{MnCl}$, and centrifuged again at $30,000 \mathrm{~g}$ for $30 \mathrm{~min}$. Pellets were stored at $-80^{\circ} \mathrm{C}$ until used.

For substance $\mathrm{P}$ binding experiments, membranes were resuspended at $0.5 \mathrm{mg} / \mathrm{ml}$ in $50 \mathrm{mM}$ Tris- $\mathrm{HCl}, \mathrm{pH} 7.4$, containing $3 \mathrm{mM} \mathrm{MnCl}, 1 \%$ bovine saline albumin, $4 \mu \mathrm{g} / \mathrm{ml}$ leupeptin, $4 \mu \mathrm{g} / \mathrm{ml}$ chymostatin, and 40 $\mu \mathrm{g} / \mathrm{ml}$ bacitracin, with or without $10 \mu \mathrm{M}$ phosphoramidon. ${ }^{125} \mathrm{I}-$ Substance $\mathrm{P}(50-70 \mathrm{cpm} / \mathrm{fmol})$ was added at $5 \mathrm{nM}$ and incubated at $25^{\circ} \mathrm{C}$. Triplicate $100-\mu \mathrm{l}$ samples were removed as a function of time and filtered (Whatman GF/A filters soaked in $0.1 \%$ polyethyleneimine for $24 \mathrm{hr}$ at $4^{\circ} \mathrm{C}$ ), and washing rapidly three times with $3.5 \mathrm{ml}$ of ice-cold $50 \mathrm{mM}$ Tris- $\mathrm{HCl}$, $\mathrm{pH} 7.4$, containing $3 \mathrm{mM} \mathrm{MnCl}_{2}$. Radioactivity on the filters was determined by scintillation counting. Specific binding was defined as the difference in counts bound in the absence and presence of $5 \mu \mathrm{M}$ unlabeled substance $P$.

Protein determination. Protein concentrations were determined by the method of Bradford (31).

Statistical analysis. Analysis of variance for substance $P$ responses in tissues from different guinea pigs indicates, at $P<0.05$, that intraanimal variation is no greater than intratissue variation. All values are expressed as mean $\pm \mathrm{SE}$. Comparisons of corresponding data points from control and experimental tissues were made using unpaired two-tailed $t$ test. Mean values were considered significantly different for $P<0.05$.

\section{Results}

Potentiation of substance $P$ responses by neutral endopeptidase inhibitors. The concentration-response curve for substance Pinduced contractions of guinea pig lung parenchymal strips relative to $\mathrm{ACh}$ is shown in Fig. 1. Under the conditions used, substance $P$ is a relatively weak agonist for inducing contractions of these tissues, stimulating maximal responses equivalent to only $30 \%$ of the ACh maximum. When tissues were pretreated with phosphoramidon $(1 \mu \mathrm{M})$, a competitive inhibitor of neutral endopeptidase, peptide responses were markedly potentiated, shifting the concentration-response curve $\sim 100$-fold to the left and increasing the magnitude of maximal responses to $100 \%$ of the ACh response (Fig. 1$)(P<0.001$ vs. control at concentrations $\left.\geq 10^{-7} \mathrm{M}\right)$. Phosphoramidon had no effect on responses to $\mathrm{ACh}$, $2 \mu \mathrm{g} / \mathrm{ml}$ resulting in a contraction of $108 \pm 5 \%(n=16)$ of the control response without drug.

Another competitive inhibitor of neutral endopeptidase, thiorphan $(1 \mu \mathrm{M})$, showed similar potentiation of substance $P$ responses (Fig. 1) $\left(P<0.001\right.$ vs. control at concentrations $\geq 10^{-7}$ M). The effect appeared to be specific for neutral endopeptidaselike activity in lung parenchymal tissues since similar potentiation was not observed with relatively specific inhibitors of other proteases. MGPA ( $1 \mu \mathrm{M})$, a carboxypeptidase $\mathrm{N}$ inhibitor, had no significant effect on substance $\mathrm{P}$-stimulated contractions of parenchymal tissues $(P>0.05)$. Captopril $(1 \mu \mathrm{M})$ caused a less marked potentiation than phosphoramidon or thiorphan, shifting the concentration-response curve to the left by a small amount and increasing maximal contractions to $40 \%$ of the $\mathrm{ACh}$ 

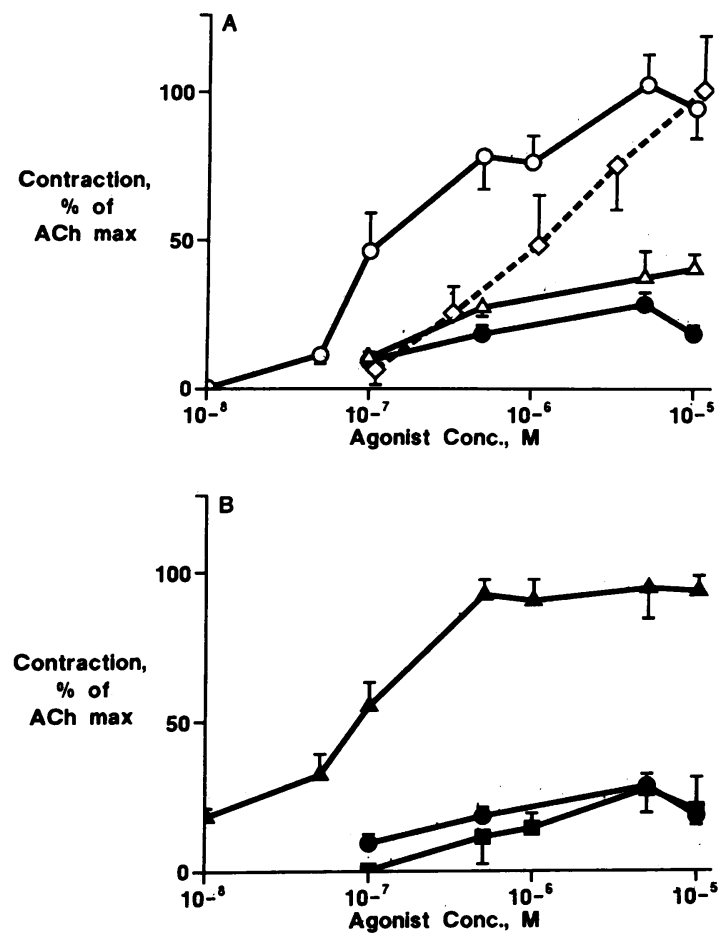

Figure 1. Concentration-response curves for contraction of guinea pig lung parenchymal strips by $(A)$ substance $P$ in Tyrode's buffer alone $(\bullet)$, in the presence of $1 \mu \mathrm{M}$ phosphoramidon (O) or $1 \mu \mathrm{M}$ captopril $(\Delta)$, and by $A C h(\diamond)$. $(B)$ Substance $P$ with $1 \mu \mathrm{M}$ thiorphan $(\Delta)$ or 1 $\mu$ M MGPA ( $\square$ ). The control curve is shown in both $A$ and $B$ to simplify comparisons. All points are the mean $\pm \mathrm{SE}(n=4-6)$. Conc., Concentration; max, maximum.

maximum (Fig. 1). The difference in responses was significant $(P<0.05)$ only at $10^{-5} \mathrm{M}$ substance $\mathrm{P}$.

Additional paired experiments were performed to rule out the possibility of a random result in the above unpaired experiments. The responses of tissues from a single animal in Tyrode's buffer alone, or in the presence of phosphoramidon or captopril (both at $1 \mu \mathrm{M}$ ) to substance $\mathrm{P}$ were compared. The $50 \%$ effective concentration $\left(\mathrm{EC}_{50}\right)$ for substance $\mathrm{P}(17 \pm 4 \%$ of $\mathrm{ACh})$ occurred at $10^{-6} \mathrm{M}$ peptide in the absence of any inhibitors or with captopril ( $n=4$ for each). In the presence of $1 \mu \mathrm{M}$ phosphoramidon, this response was achieved at $5 \times 10^{-8} \mathrm{M}$ substance $\mathrm{P}(n=4)$. At $5 \times 10^{-6} \mathrm{M}$ substance $P$, the magnitude of the response in control tissues was only $33 \%$ of that observed in the presence of phosphoramidon ( $33 \pm 4$ vs. $100 \pm 10 \%$ of $\mathrm{ACh}, n=4$ for each). The responses obtained in paired experiments were not significantly different from unpaired data $(P<0.05)$.

Recovery of substance $P$ from lung parenchymal strips. Previous investigators have shown that phosphoramidon and thiorphan inhibit the proteolytic activity of neutral endopeptidase $(17,19)$. The pharmacologic data of Fig. 1 are consistent with such action, i.e., potentiation of the biological activity of substance $P$ as a result of inhibiting its degradation. To examine this possibility, the amount of intact substance $P$ remaining after 5 min incubation with lung parenchymal tissues was determined. The amount of tissue per milliliter of buffer was similar to that used in muscle baths and the incubation period chosen was comparable to the time required to develop a tissue response. Substance $P$ was added at an initial concentration of $1 \mu \mathrm{M}$. HPLC profiles of the substance $P$ recovered from these incubation mixtures are shown in Fig. 2. Recovery of the peptide from control mixtures without tissue was essentially quantitative $(\geq 97 \%)$. Under these incubation conditions, only $9.5 \%$ of the substance $P$ added was recovered intact after $5 \mathrm{~min}$. Inclusion of $1 \mu \mathrm{M}$ phosphoramidon provided significant protection from degradation, with $47 \%$ of the peptide recovered as intact substance $P$ after $5 \mathrm{~min}(P<0.005)$. Neither captopril nor MGPA had a significant effect compared with the control $(P=0.05)$ (Fig. 2, Table I).

In preparation for the receptor binding experiments described below, the degradation of substance $P$ was additionally studied using guinea pig lung membrane preparations (Table II). In the absence of inhibitors, substance $P$ was degraded at a rate of 8.1 $\mathrm{nmol} / \mathrm{min}$ per $\mathrm{mg}$ protein. In the presence of $1 \mu \mathrm{M}$ phosphor-
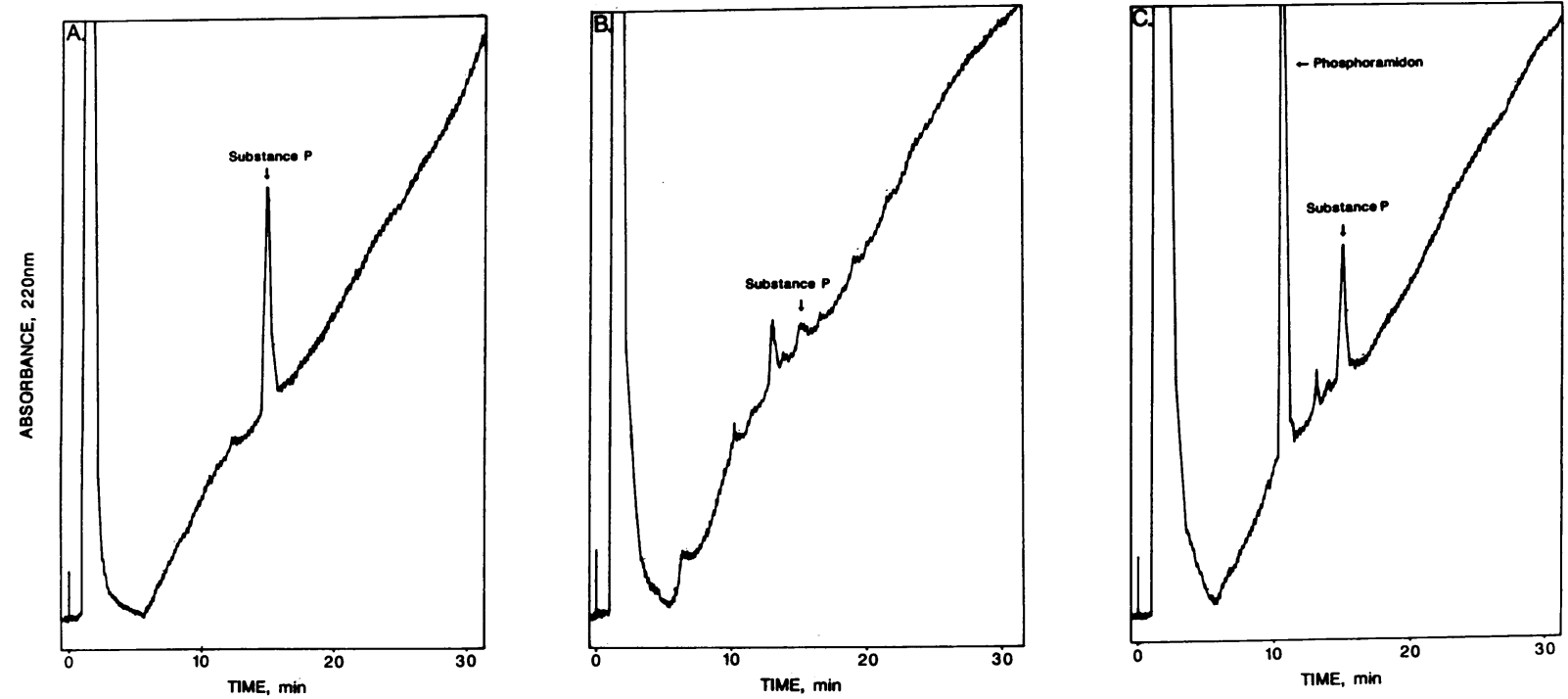

Figure 2. Representative HPLC profiles of substance $P$ recovered from incubation mixtures with guinea pig lung strips. A volume initially containing $1 \mathrm{nmol}$ was injected for each incubation condition. $(A)$ Control without tissue. $(B) 5$ min at $37^{\circ} \mathrm{C}$ with $160 \mathrm{mg}$ lung tissue. $(C)$ Same as $B$ with $1 \mu \mathrm{M}$ phosphoramidon. 
Table I. Recovery of Substance P from

Guinea Pig Lung Parenchymal Tissues

\begin{tabular}{ll}
\hline Inhibitor & \% Recovery \\
\hline None & $10 \pm 1$ \\
Phosphoramidon $(1 \mu \mathrm{M})$ & $47 \pm 3^{*}$ \\
Captopril $(1 \mu \mathrm{M})$ & $15 \pm 4^{\ddagger}$ \\
MGPA $(1 \mu \mathrm{M})$ & $17 \pm 3^{\ddagger}$
\end{tabular}

Guinea pig lung tissues $(160 \mathrm{mg})$ were incubated with $1 \mu \mathrm{M}$ substance $\mathrm{P}$ in $5 \mathrm{ml}$ Tyrode's buffer at $37^{\circ} \mathrm{C}$ for $5 \mathrm{~min}$ with the inhibitors indicated. Recovery of intact substance $P$ was quantitated as described in Methods. Data are the means \pm SE of triplicate experiments using tissues from three different animals.

* Significantly different from the control without inhibitors $(P<0.005)$.

${ }^{\ddagger}$ Not significantly different from control at $P=0.05$.

amidon the rate of degradation was reduced by $65 \%$, to $2.9 \mathrm{nmol} /$ min per $\mathrm{mg}$ protein $(P<0.005)$. MGPA had no significant effect compared with the control $(P=0.05)$.

Specificity of proteolytic activity for substance $P$. The synthetic chemotactic peptide, fMLP, is also spasmogenic for guinea pig lung parenchymal strips $(32,33)$ and is reported to be degraded by neutral endopeptidase present on human neutrophils (14). The concentration-response curves for fMLP-induced contractions of guinea pig lung parenchymal strips in Tyrode's buffer alone and in the presence of phosphoramidon are shown in Fig. 3. This formylated tripeptide is much more potent than substance P for contracting lung parenchymal strips, with threshold responses at subnanomolar concentrations and maximal contractions in excess of $200 \%$ of ACh. Inhibition of neutral endopeptidase activity with phosphoramidon resulted in only a three- to fourfold increase in $\mathrm{MLP}$ responses, a much smaller potentiation than was observed for substance P. Contractile responses are significantly different from control $(P<0.05)$ only for fMLP concentrations of $5 \times 10^{-9} \mathrm{M}$ and below.

The spasmogenic activity of the complement anaphylatoxin peptides, $\mathrm{C} 3 \mathrm{a}$ and $\mathrm{C} 5 \mathrm{a}$, was also tested for potentiation by phosphoramidon (Fig. 3). C5a is active in a concentration range similar to fMLP and C3a causes responses in a range comparable to substance $P$ in the absence of protease inhibitors. Phosphoramidon did not significantly effect the concentration-response curve for either of these peptides $(P=0.50)$ (Fig. 3).

Table II. Degradation of Substance P by Guinea Pig Lung Membrane Preparations: Effect of Protease Inhibitors

\begin{tabular}{ll}
\hline Inhibitor & Rate of degradation \\
\hline None & $8.1 \pm 0.7$ \\
$1 \mu \mathrm{M}$ phosphoramidon & $2.9 \pm 0.6$ \\
$1 \mu \mathrm{M}$ MGPA & $8.1 \pm 0.2$
\end{tabular}

Guinea pig lung membranes, suspended at $0.5 \mathrm{mg} / \mathrm{ml}$ in $50 \mathrm{mM}$ Tris$\mathrm{HCl}, \mathrm{pH} 7.0$, were incubated with $100 \mu \mathrm{M}$ substance $\mathrm{P}$ at $37^{\circ} \mathrm{C}$. 100$\mu \mathrm{l}$ aliquots were removed in duplicate at $0,1,2,5,10$, and $20 \mathrm{~min}$, degradation was terminated, and the rate of substance $P$ degradation was determined as described in Methods. Mean \pm SE of two separate experiments.

* Data are expressed as nanomoles per minute per milligram protein \pm SE.
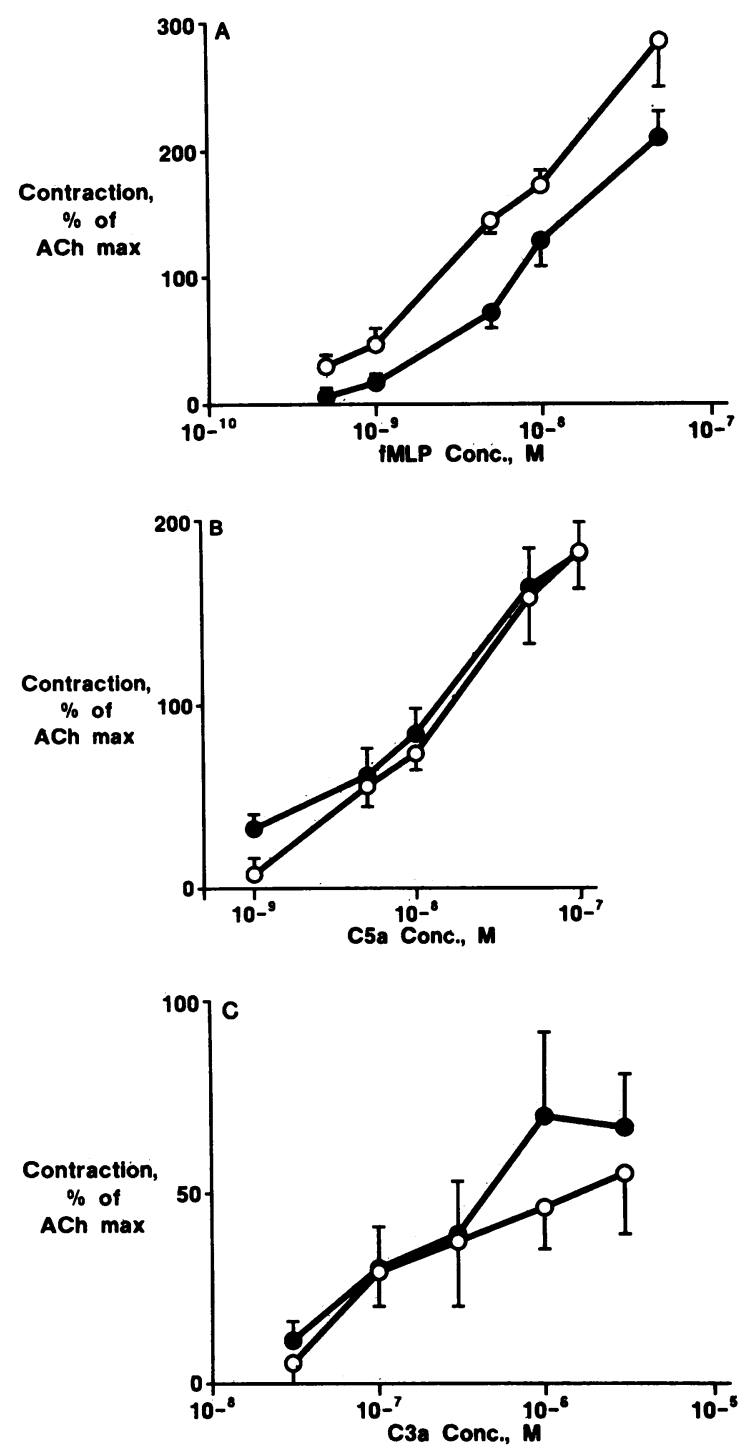

Figure 3. Effect of $1 \mu \mathrm{M}$ phosphoramidon on the concentration-response curves for guinea pig lung parenchymal strips with fMLP $(A)$, C5a $(B)$, and C3a $(C)$. Control in Tyrode's buffer alone $(\bullet)$ or in the presence of $1 \mu \mathrm{M}$ phosphoramidon (0). All points are the mean $\pm \mathrm{SE}$ $(n=4-8)$. Conc., Concentration; max, maximum.

Inhibition of the potentiated substance $P$ response by a specific receptor antagonist. The snythetic peptide antagonist of substance P; D-Pro ${ }^{2}$, D-Phe 7 , D-Trp ${ }^{9}$-substance P has been shown to block substance $P$ responses by binding nonproductively to the substance $P$ receptor (34). In the presence of phosphoramidon, the substance $P$ concentration-response curve was significantly inhibited $\left(P<0.05\right.$ for all concentrations except $\left.10^{-5} \mathrm{M}\right)$ by $1 \mu \mathrm{M}$ D-Pro ${ }^{2}$, D-Phe ${ }^{7}$, D-Trp ${ }^{9}$-substance P (Fig. 4), supporting the evidence for an increase in activity of substance $P$ on its receptor on lung parenchymal strips in the presence of phosphoramidon. At higher concentrations the peptide antagonist also expresses weak agonist activity (not shown).

Effect of phosphoramidon on specific binding of substance $P$ to bronchial membrane receptors. Specific binding of $5 \mathrm{nM}^{125} \mathrm{I}-$ substance $\mathbf{P}$ to bronchial membrane preparations was performed in the presence of the protease inhibitors, leupeptin, chymostatin, and bacitracin, which are reported to prevent degradation of 


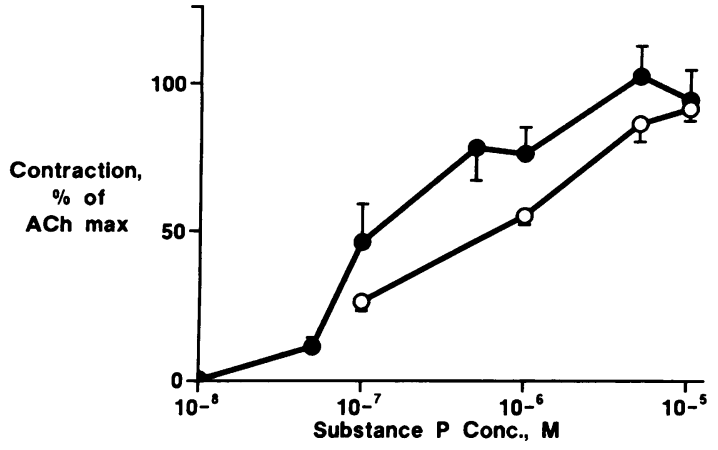

Figure 4. Concentration-response curves for substance $\mathrm{P}$ in the presence of $1 \mu \mathrm{M}$ phosphoramidon alone, as in Fig. $1(\bullet)$ or in addition to $1 \mu \mathrm{M}$ D-Pro ${ }^{2}$, D-Phe ${ }^{7}$, D-Trp ${ }^{9}$-substance $\mathrm{P}(\mathrm{O})$. All points are the mean $\pm S E(n=4-6)$. Conc., Concentration; max, maximum.

substance $P$ in other tissues (34-36). In the absence of the neutral endopeptidase inhibitor in combination with these other compounds, specific uptake of substance $\mathrm{P}$ at $25^{\circ} \mathrm{C}$ reached a maximum of $80-100 \mathrm{fmol} / \mathrm{mg}$ protein by $2-5 \mathrm{~min}$ and rapidly dropped to nearly undetectable levels (Fig. 5). When $10 \mu \mathrm{M}$ phosphoramidon was combined with the other protease inhibitors, uptake reached a maximum by $10 \mathrm{~min}$ and remained stable for at least $10 \mathrm{~min}$ thereafter at a level almost four times as great as in incubation mixtures without phosphoramidon (Fig. 5). The concentration of $10 \mu \mathrm{M}$ phosphoramidon was chosen to ensure the stability of the relatively low ${ }^{125}$ I-substance $P$ levels in these incubation conditions. This agent is not reported to have nonspecific effects at this concentration.

Effect of neutral endopeptidase inhibitors on substance $P$ induced responses of guinea pig tracheal tissues. The potency of substance $\mathbf{P}$ for contracting guinea pig tracheal rings in Tyrode's buffer alone is considerably greater than for contracting lung parenchymal strips (Fig. 6, and reference 8). Threshold contractions of trachea were observed at 10-100 nM substance $P$ and maximal responses induced were equivalent to $120 \%$ of the

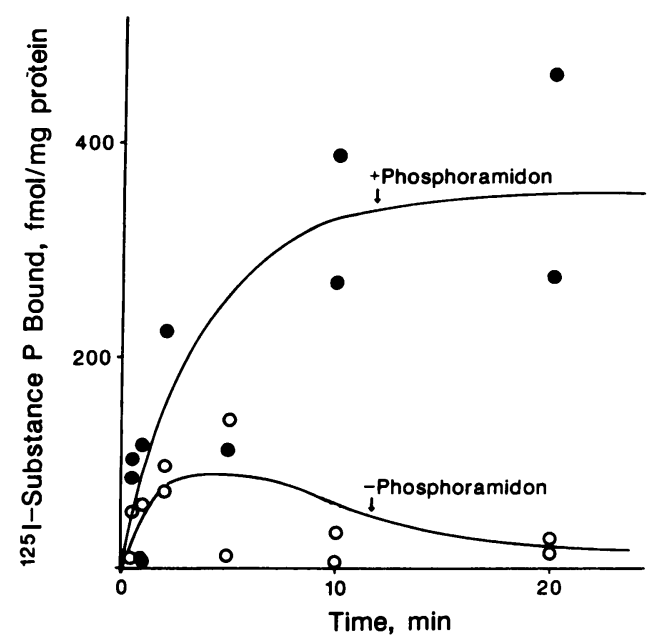

Figure 5. Effect of phosphoramidon on the specific binding of $5 \mathrm{nM}$ ${ }^{125}$ I-substance $P$ to bronchial membranes in the presence of $4 \mu \mathrm{g} / \mathrm{ml}$ leupeptin, $4 \mu \mathrm{g} / \mathrm{ml}$ chymostatin, and $40 \mu \mathrm{g} / \mathrm{ml}$ bacitracin. (O) Without phosphoramidon; (๑) with $10 \mu \mathrm{M}$ phosphoramidon. Each point is the mean of triplicate determinations corrected for nonspecific binding with $5 \mu \mathrm{M}$ unlabeled substance $\mathrm{P}$.

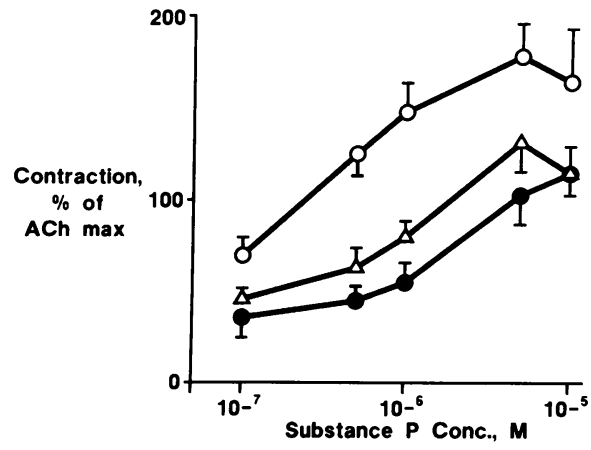

Figure 6. Concentration-response curves for contraction of guinea pig tracheal rings by substance $\mathrm{P}$ in Tyrode's buffer alone $(\bullet)$, with $1 \mu \mathrm{M}$ captopril $(\Delta)$, or with $1 \mu \mathrm{M}$ phosphoramidon (o). All points are the mean \pm SE $(n=4-6)$. Conc., Concentration; max, maximum.

ACh maximum response (Fig. 6). In the presence of phosphoramidon, tracheal responses are potentiated $\sim 50$-fold and maximal responses are increased to $180 \%$ of the $\mathrm{ACh}$ maximum ( $P$ $<0.01$ for all concentrations. As observed for lung parenchymal strips, captopril produced a trend towards increasing responses to substance $P$ but did not significantly shift the dose-response curve $(P=0.05)$.

\section{Discussion}

The work reported here was prompted by the observation that substance $P$ is a relatively weak agonist for producing contractile responses in guinea pig lung parenchymal strips under the experimental conditions normally used (i.e., Tyrode's buffer with no additives) $(26,29)$. Reports that substance $P$ is a substrate for neutral endopeptidase $(10,37)$, coupled with observations that this enzyme is present in lung epithelium $(15,38)$, encouraged us to examine the contractile activity of the peptide in the presence of inhibitors of this enzyme. Our findings show potentiation of substance $P$ responses by 100 -fold on lung parenchymal strips in the presence of relatively specific inhibitors of neutral endopeptidase, including phosphoramidon and thiorphan (Fig. 1). Responses of tracheal tissues were also greatly enhanced in the presence of phosphoramidon, shifting the concentration-response curve to 50 -fold lower concentrations (Fig. 6).

Angiotensin converting enzyme is also reported to degrade substance $\mathrm{P}$ (10); however, captopril, at $1 \mu \mathrm{M}$, potentiates the substance $P$ concentration-response curve for lung parenchymal strips by a relatively small amount, statistically significant only at the highest substance $P$ concentration tested (Fig. 1). Tracheal tissue responses were not significantly affected (Fig. 6). Higher concentrations of these inhibitors were not tested in this system since previous investigations have shown, using purified enzymes, that $1 \mu \mathrm{M}$ captopril completely blocks substance $P$ degradation by angiotensin converting enzyme and similarly, $1 \mu \mathrm{M}$ phosphoramidon completely blocks degradation of this peptide by purified neutral endopeptidase (10). Thus, in lung tissues, the data presented here indicate that neutral endopeptidase, or a neutral endopeptidase-like enzyme, is highly active in limiting the biological activity of substance $P$, and is more important in this regard than angiotensin converting enzyme.

Incubation of $1 \mu \mathrm{M}$ substance $\mathrm{P}$ with guinea pig lung tissues for $5 \mathrm{~min}$ at $37^{\circ} \mathrm{C}$ resulted in degradation of $90 \%$ of the peptide (Fig. 2, Table I). Phosphoramidon at $1 \mu \mathrm{M}$ resulted in significant 
protection from degradation, with $47 \%$ of the peptide remaining intact after $5 \mathrm{~min}$. Neither captopril nor MGPA improved the recovery of substance $P$ from lung strips compared with the control.

The rate of substance $P$ degradation was also studied using washed guinea pig lung membrane preparations, which are predicted to be a source of neutral endopeptidase activity (15). In incubation mixtures containing $500 \mu \mathrm{g}$ membrane protein $/ \mathrm{ml}$ and $100 \mu \mathrm{M}$ substance $\mathrm{P}$, peptide was degraded at a rate of 8.1 $\mathrm{nmol} / \mathrm{min}$ per $\mathrm{mg}$ protein (Table II). In the presence of phosphoramidon, this rate was inhibited by $65 \%$ to $2.9 \mathrm{nmol} / \mathrm{min}$ per mg protein. The serum carboxypeptidase inhibitor, MGPA, had no effect compared with the control. Thus the phosphoramidon-induced potentiation of substance $P$ responses appears to result from a decreased rate of degradation of the peptide.

Clearly, substance $P$ is still degraded by other enzymes present in lung tissues, even in the presence of phosphoramidon (Table I). Investigations of binding sites for this peptide in rat brain and guinea pig gastrointestinal smooth muscle preparations have demonstrated a requirement for a combination of leupeptin, chymostatin, and bacitracin to prevent degradation (35, 36, 39). This combination of inhibitors did not block substance $\mathbf{P}$ degradation by crude lung membrane preparations. However, when phosphoramidon was also added, recovery of intact substance $\mathrm{P}$ was $70-80 \%$ after $30 \mathrm{~min}$ incubation at $25^{\circ} \mathrm{C}$ (data not shown). When tested on guinea pig lung parenchymal strips in the muscle bath, this combination of inhibitors did not potentiate substance $P$ responses more than phosphoramidon alone (data not shown), which suggested that this additional proteolytic activity is not kinetically competitive with the initial interaction of substance $P$ with its cellular receptor.

To confirm the competitive nature of phosphoramidon-inhibitable substance $P$ degradation with binding of the peptide to its receptor, uptake of the peptide was studied as a function of time. Experiments were initially performed using a membrane preparation from the entire lung; however, the data obtained indicate, as previously reported (9), that this preparation does not contain a sufficiently high receptor density to detect specific binding. Autoradiographic localization of substance $P$ receptors in guinea pig lung indicate the highest receptor density on bronchial smooth muscle (9), and therefore the bronchial membrane preparation described was used instead. This preparation is estimated to be enriched three- to fourfold in bronchial membranes compared with the intact lung. Phosphoramidon resulted in a 3.5- to 4-fold increase in the specific binding of ${ }^{125} \mathrm{I}$-substance $P$ compared with the control without neutral endopeptidase inhibitor (Fig. 5). Binding increased and remained stable for at least 20 min with phosphoramidon, but returned to nearly undetectable levels within $10 \mathrm{~min}$ in the controls.

The selectivity of the phosphoramidon-induced hyperresponsiveness was relatively specific for substance $P$ among the additional peptide spasmogens tested. The formylated tripeptide, fMLP, was potentiated only three- to fourfold by phosphoramidon (Fig. 3). Connelly et al. (14) report degradation of AMLP by neutral endopeptidase present on human neutrophil membranes. However, this enzyme activity in lung appears to be a relatively unimportant control mechanism for fMLP-induced contractile responses of isolated lung tissues compared with substance $\mathbf{P}$.

The spasmogenic activities of the anaphylatoxin peptides, C3a and C5a, were not significantly affected by neutral endopeptidase inhibitors (Fig. 3). Both these peptides are known to be inactivated by serum carboxypeptidase (23). C3a has additionally been shown to be a substrate for purified angiotensin converting enzyme in vitro (40), and evidence exists for inactivation of C5a by aminopeptidase or endopeptidase activity $(41,42)$. These spasmogenic peptides may be too large to be effective substrates for neutral endopeptidase.

The pharmacologic and receptor-binding data indicate that the increase in longevity of substance $P$ in lung tissues is manifested by an increase in the interactions between the peptide and its receptor. This is further supported by inhibition of phosphoramidon-potentiated substance $P$ responses in the presence of the specific receptor antagonist, D-Pro ${ }^{2}$, D-Phe ${ }^{7}$, D-Trp ${ }^{9}-$ substance $P$. This peptide analogue, at $1 \mu \mathrm{M}$, shifted the substance $\mathbf{P}$ dose-response curve, in the presence of phosphoramidon, to five- to tenfold higher concentrations (Fig. 4).

These data identify the potential activity of substance $P$ for contracting guinea pig lung parenchymal strips and tracheal rings in vitro when degradation by neutral endopeptidase-like activity is blocked. Thus, this peptide is a much more potent agonist for producing smooth muscle contraction in these tissues than was previously appreciated. Furthermore, these findings suggest that the levels of neutral endopeptidase activity in the lung play a key role in controlling the biological activity of endogenous substance $\mathbf{P}$.

Little information is available relative to the control of expression of this enzyme activity in vivo. Johnson et al. (43) reported significant elevation in neutral endopeptidase activity in the blood of patients with adult respiratory distress syndrome. These authors speculated that this activity may derive from injured cells in the lung (14). If this circumstance results in diminished levels of enzyme activity in the lung, then, based on the present report, one might expect to observe marked potentiation of the pathophysiologic effects of endogenously released substance $P$. This report may therefore expose a potentially important and heretofore unrecognized control mechanism of pulmonary responses mediated by substance $P$ under the direct control of neutral endopeptidase.

\section{Acknowledgments}

The author would like to thank Althea Burrier for expert technical assistance.

This work was supported by National Institutes of Health (NIH) grant HL-36162. Dr. Stimler-Gerard is the recipient of NIH Research Career Development Award HL-01777.

\section{References}

1. Chang, M. M., S. E. Leeman, and H. D. Niall. 1971. Amino acid sequence of substance P. Nature New Biol. 232:86.

2. Lundberg, J. M., E. Brodin, and A. Saria. 1983. Effects and distribution of vagal capsaicin-sensitive substance $P$ neurons with special reference to the trachea and lungs. Acta Physiol. Scand. 119:243-252.

3. Lundberg, J. M., C. R. Martling, and A. Saria. 1983. Substance $P$ and capsaicin-induced contraction of human bronchi. Acta Physiol. Scand. 119:49-53.

4. Lundberg, J. M., and A. Saria. 1982. Bronchial smooth muscle contraction induced by stimulation of capsaicin-sensitive vagal sensory neurons. Acta Physiol. Scand. 116:473-476.

5. Nilsson, G., K. Dahlberg, E. Brodin, F. Sundler, and K. Strandberg. 1977. Distribution and constrictor effect of substance $P$ in guinea pig tracheo-bronchial tissue. In Substance P. U. S. von Euler and B. Pernow, editors. Raven Press, New York. 75-81. 
6. Malo, P. E., M. A. Wasserman, T. J. Torphy, D. J. Parris, and D. E. Pfeiffer. 1986. Characterization of substance P-induced contractions of guinea pig trachea. J. Pharm. Exp. Ther. 237:782-786.

7. Mizarahi, J., R. Couture, S. Caranikas, and D. Regoli. 1982. Pharmacological effects of peptides on tracheal smooth muscle. Pharmacology. 25:39-50.

8. Regal, J. F., and D. E. Johnson. 1983. Indomethacin alters the effects of substance $P$ and VIP on isolated airway smooth muscle. Peptides. 4:581-584.

9. Carstairs, J. R., and P. J. Barnes. 1986. Autoradiographic mapping of substance $P$ receptors in lung. Eur. J. Pharmacol. 127:295-296.

10. Skidgel, R. A., S. Englebrecht, A. R. Johnson, and E. G. Erdos. 1984. Hydrolysis of substance $P$ and neurotensin by converting enzyme and neutral endopeptidase. Peptides. 5:769-776.

11. Schwartz, J.-C., B. Malfroy, and S. DeLa Baume. 1981. Biological inactivation of enkephalins and role of enkephalin-dipeptidyl carboxypeptidase (enkephalinase) as neuropeptidase. Life Sci. 29:1715-1740.

12. Gafford, J. T., R. A. Skidgel, E. G. Erdos, and L. B. Hersh. 1983. Human kidney enkephalinase, a neutral metalloendopeptidase that cleaves active peptides. Biochemistry. 22:3265-3271.

13. Matsas, R., I. S. Fulcher, A. J. Kenny, and A. J. Turner. 1983. Substance $P$ and [Leu]-enkephalin are hydrolyzed by an enzyme in pig caudate synaptic membranes that is identical with the endopeptidase of kidney microvilli. Proc. Natl. Acad. Sci. USA. 80:3111-3115.

14. Connelly, J. C., R. A. Skidgel, W. W. Schultz, and A. R. Johnson. 1985. Neutral endopeptidase 24.11 in human neutrophils: cleavage of chemotactic peptide. Proc. Natl. Acad. Sci. USA. 82:8737-8741.

15. Johnson, A. R., J. Ashton, W. W. Schultz, and E. G. Erdos. 1985. Neutral metalloendopeptidase in human lung tissue and cultured cells. Am. Rev. Respir. Dis. 132:564-568.

16. Waksman, G., E. Hamel, M.-C. Fournie-Zaluski, and B. P. Roques. 1986. Autoradiographic comparison of the distribution of the neutral endopeptidase $\pi$ enkephalinase $\pi$ and of the mu and delta opiod receptors in rat brain. Proc. Natl. Acad. Sci. USA. 83:1523-1527.

17. Hudgin, R. L., S. E. Charleson, M. Zimmerman, R. Mumford, and P. L. Wood. 1981. Enkephalinase-selective peptide inhibitors. Life Sci. 29:2593-2601.

18. Llorens, C., G. Gacel, J. P. Swerts, R. Perdrisot, M. C. FournieZaluski, J. C. Schwartz, and B. P. Roques. 1980. Rational design of enkephalinase inhibitors: Substrate specificity of enkephalinase studied from inhibitory potency of various dipeptides. Biochem. Biophys. Res. Commun. 96:1710-1717.

19. Mumford, R. A., P. A. Pierzchala, A. W. Strauss, and M. Zimmerman. 1981. Purification of a membrane-bound metalloendopeptidase from porcine kidney that degrades peptide hormones. Proc. Natl. Acad. Sci. USA. 78:6623-6627.

20. Nishino, N., and J. C. Powers. 1979. Design of potent reversible inhibitors for thermolysin. Peptides containing zinc coordinating ligands and their use in affinity chromatography. Biochemistry. 18:4340-4347.

21. Malfroy, B., J. P. Swerts, A. Guyon, B. P. Roques, and J. C. Schwartz. 1978. High affinity enkephalin-degrading peptidase in brain is increased after morphine. Nature (Lond.). 276:523-526.

22. Sullivan, S., H. Akil, and J. D. Barchas. 1978. In vitro degradation of enkephalin: evidence for cleavage at the Gly-Phe bond. Commun. Psychopharmacol. 2:525-531.

23. Bokisch, V. A., and H. J. Muller-Eberhard. 1970. Anaphylatoxin inactivator of human plasma. Its isolation and characterization as a carboxypeptidase. J. Clin. Invest. 49:2427-2436.

24. Yang, H. Y. T., and E. G. Erdos. 1967. Second kininase in human blood plasma. Nature (Lond.). 215:1402-1403.

25. Franke, A. E., G. C. Andrews, N. P. Stimler-Gerard, C. Gerard, and H. J. Showell. 1986. Human C5a anaphylatoxin: gene synthesis, expression, and recovery of biologically active material from $E$. coli. Methods Enzymol. In press.

26. Stimler, N. P., T. E. Hugli, and C. M. Bloor. 1980. Pulmonary injury induced by C3a and C5a anaphylatoxins. Am. J. Pathol. 100:327348.

27. Brocklehurst, W. E. 1978. The handling and assay of mediators in hypersensitivity reactions. Handbook Exp. Immunol. 46:1-20.

28. Stimler, N. P., M. K. Bach, C. M. Bloor, and T. E. Hugli. 1982. Release of leukotrienes from guinea pig lung stimulated by $\mathrm{C}^{2} \mathrm{a}_{\mathrm{des}} \mathrm{Arg}$ anaphylatoxin. J. Immunol. 128:2247-2252.

29. Regal, J. F., A. Y. Eastman, and R. J. Pickering. 1980. C5a induced tracheal contraction: A histamine independent mechanism. $J$. Immunol. 124:2876-2878.

30. Pong, S. S., and R. N. Dehaven. 1983. Characterization of a leukotriene $\mathrm{D}_{4}$ receptor in guinea pig lung. Proc. Natl. Acad. Sci. USA. 80:7415-7419.

31. Bradford, M. M. 1976. A rapid and sensitive method for the quantitation of microgram quantities of protein utilizing the principle of protein-dye binding. Anal. Biochem. 72:248-254.

32. Burka, J. F. 1984. Effects of compound $48 / 80$ and formylmethionyl-leucyl-phenylalanine on isolated guinea pig airways. Inst. Arch. Allergy Appl. Immunol. 73:309-313.

33. Hamel, R., A. W. Ford-Hutchinson, A. Lord, and M. Cirino. 1984. Bronchoconstriction induced by $\mathrm{N}$-formyl-methionyl-leucyl-phenylalanine in the guinea pig, involvement of arachidonic acid metabolites. Prostaglandins. 28:43-56.

34. Jiang, Z.-G., N. J. Dun, and A. G. Karczmar. 1982. Substance $\mathrm{P}:$ a putative sensory transmitter in mammalian autonomic ganglia. Science (Wash. DC). 217:739-741.

35. Burcher, E., S. H. Buck, W. Lovenberg, and T. L. O'Donohue. 1986. Characterization and autoradiographic localization of multiple tachykinin sites in gastrointestinal tract and bladder. J. Pharmacol. Exp. Ther. 236:819-831.

36. Cascieri, M. A., G. G. Chicci, and T. Liang. 1985. Demonstration of two distinct tachykinin receptors in rat brain cortex. J. Biol. Chem. 260:1501-1507.

37. Turner, A. J., R. Matsas, and A. J. Kenny. 1985. Are there neuropeptide-specific peptidases? Biochem. Pharmacol. 34:1347-1356.

38. Giros, B., C. Gros, C. Llorens, B. Malfroy, C. Rose, K. Zuzel, H. Pollard, I. Pachot, J.-C. Schwartz, L. Beu Natan, P. Chaillet, J. Costenti, and J.-C. Mazie. 1985. Biological inactivation of enkephalins and the role of enkephalin-dipeptidyl-carboxypeptidase as neuropeptidase. In Substances opiodes medullaires et analgesie. Vol. 127. J.-M. Besson and Y. Lazorthes, editors. 57-86. Inserm, Paris.

39. Schults, C. W., R. Quirion, B. Chronwall, T. N. Chase, and T. L. O'Donohue. 1984. A comparison of the anatomical distribution of substance $P$ and substance $P$ receptors in the rat central nervous system. Peptides. 5:1097-1128.

40. Stimler, N. P., C. L. Hendricks, J. B. Ozols, and C. Gerard. 1985. Complement anaphylatoxins as substrates for angiotensin-converting enzyme. Fed. Proc. 44:1267. (Abstr.)

41. Damerau, B., B. Zimmerman, H. Wustefeld, K. Czorniak, and W. Vogt. 1986. Involvement of the $\mathrm{N}$ terminus of hog $\mathrm{C} 3 \mathrm{a}, \mathrm{C} 5 \mathrm{a}$, and C5 $\mathrm{a}_{\text {des Arg }}$ in their biological activities. Mol. Immunol. 23:433-440.

42. Gerard, C., H. Showell, P. D. Hoeprich, T. E. Hugli, and N. P. Stimler. 1985. Evidence for a role of the amino-terminal region in the biological activity of the classical anaphylatoxin, porcine C5a $\mathrm{a}_{\text {des Arg-74 }} \mathrm{J}$. Biol. Chem. 260:2613-2616.

43. Johnson, A. R., J. J. Coalson, J. Ashton, M. Larumbide, and E. G. Erdos. 1985. Neutral endopeptidase in serum samples from patients with adult respiratory distress symdrome. Am. Rev. Respir. Dis. 132: 1262-1267. 